\title{
PENGEMBANGAN DASAR KEBUTUHAN RENCANA KEGIATAN PEMBELAJARAN BERORIENTASI SAINS PADA SUB TEMA AIR UNTUK MENGOPTIMALKAN KETERAMPILAN MENGAMATI ANAK USIA DINI
}

\author{
Wasilah Nur Adawiyah ${ }^{1}$, Edi Hendri Mulyana ${ }^{2}$, Elan $^{3}$ \\ ${ }^{1}$ Universitas Pendidikan Indonesia Kampus Tasikmalaya \\ ${ }^{2}$ Universitas Pendidikan Indonesia Kampus Tasikmalaya \\ ${ }^{3}$ Universitas Pendidikan Indonesia Kampus Tasikmalaya
}

Email: wasilahnur74@gmail.com

(Received: Mei 2020; Accepted: Mei 2020; Published: Juni 2020)

\begin{abstract}
Research and development has been carried out, which aims find out the basic needs of developing scienceoriented learning activity plans on the water sub theme to optimize early childhood observation skills. Metode penelitian yang dilakukan menggunakan metode pengembangan, model pendekatan mix method dengan teknik Educational Design Research mengacu pada model menurut McKenney dan Reeves. This article only explains the Educational Design Research engineering research in the first stage, namely the exploration and analysis of research problems. Data collection was carried out with preliminary studies, namely field studies with initial observations and literature studies. The field study was conducted at Raudhatul Athfal AT-Taufiq which is located in Cibeureum Sub-district, Tasikmalaya City. Literature study is carried out by examining the journals and the results of previous research related to problems and science-oriented books in early childhood. Thus, the results of the study indicate various basic needs for developing science-oriented learning activity plans to optimize observational skills, which will later be used as a reference or guideline for designing research development products in the form of learning activity plans.
\end{abstract}

\begin{abstract}
ABSTRAK
Telah dilakukan penelitian dan pengembangan, yang bertujuan untuk mengetahui dasar kebutuhan pengembangan rencana kegiatan pembelajaran berorientasi sains pada sub tema air untuk mengoptimalkan keterampilan mengamati anak usia dini. Metode penelitian yang dilakukan menggunakan metode pengembangan, model pendekatan mix method dengan teknik Educational Design Research mengacu pada model menurut McKenney dan Reeves. Artikel ini hanya menjelaskan penelitian teknik Educational Design Research pada tahap pertama yaitu tahap eksplorasi dan analisis masalah penelitian. Pengumpulan data dilakukan dengan studi pendahuluan yaitu studi lapangan dengan observasi awal dan studi literatur. Studi lapangan dilaksanakan di Raudhatul Athfal AT-Taufiq yang beralamat di Kecamatan Cibeureum Kota Tasikmalaya. Studi literatur dilakukan dengan mengkaji jurnal dan hasil penelitian terdahulu terkait permasalahan serta buku-buku berorientasi sains pada anak usia dini. Sehingga, hasil penelitian menunjukan berbagai kebutuhan dasar untuk mengembangkan rencana kegiatan pembelajaran berorientasi sains untuk mengoptimalkan keterampilan mengamati, yang nantinya akan dijadikan sebagai acuan atau pedoman untuk perancangan produk pengembangan penelitian berupa rencana kegiatan pembelajaran.
\end{abstract}

Keywords: Learning activities; Science ; Early childhood; observe 


\section{PENDAHULUAN}

Pendidikan anak usia dini merupakan pendidikan yang diselenggarakan sebelum pendidikan dasar, bagi anak usia 0-6 tahun, pada masa ini sering disebut golden age atau masa emas. Masa emas merupakan masa dimana perkembangan pada anak begitu pesat. Maka, untuk mengoptimalkan masa emas anak, pendidikan dibutuhkan agar anak mampu berkembang sesuai harapan untuk kehidupan selanjutnya. Sejalan dengan itu, menurut Sujiono (2013:7) :

Pendidikan anak usia dini merupakan upaya perawatan, pengasuhan dan pendidikan pada anak dengan menciptakan lingkungan dimana anak dapat mengeksplorasi pengalaman yang memberikan kesempatan padanya untuk mengetahui dan memahami. Anak usia dini yang merupakan peserta didik menjadi prioritas utama, dalam proses pembelajaran yang diselenggarakan. Pendidikan anak usia dini berperan penting bagi perkembangan awal anak, yang menjadi dasar bagi perkembangan anak selanjutnya.

Anak usia dini mengalami proses perkembangan yang mendasar, yaitu pengalaman perkembangan ketika usia dini akan berpengaruh dan membekas dalam jangka waktu lama, sehingga menjadi pondasi untuk proses perkembangan anak selanjutnya. Maka, pembelajaran pada pendidikan anak usia dini harus sesuai dengan usia perkembangan anak.

Salah satu aspek perkembangan yang harus dikembangkan pada anak, yaitu aspek perkembangan kognitif. Aspek perkembangan kognitif merupakan kemampuan otak anak dalam berpikir dan memperoleh informasi. Pembelajaran yang dapat mengembangkan kemampuan kognitif anak, salah satunya adalah pembelajaran sains.
Menurut Carin \& Sund (dalam Atmojo, 2013) "Sains adalah pengetahuan yang tersusun secara teratur atau sistematis, dan merupakan hasil dari observasi atau pengamatan dan eksperimen." Sund and Corring (1993:37) merumuskan bahwa sains merupakan :

Kumpulan pengetahuan dan caracara untuk mendapatkan dan mempergunakan pengetahuan itu. Pendekatan yang digunakan dalam kegiatan belajar sains kepada anak sangat tergantung pada pengalaman, usia dan tingkat perkembangnnya. Pembelajaran sains sejak dini sangatlah baik untuk proses kematangan berpikir anak. Dengan pembelajaran sains seorang anak akan memiliki pola berpikir ilmiah pada otak kirinya sebab didalamnya anak akan diajak untuk berfikir analitis, mengaitkan hubungan antara sebab dan akibat, kemudian menarik sebuah kesimpulan dari hubungan tersebut. Terdapat hasil penelitian yang menunjukan, bahwa sains sangat berpengaruh baik terhadap perkembangan individu dalam berbagai aspek (Trundle \& Bell, 2010). Trundle, (2009: 1), menyatakan bahwa "Pembelajaran sains pada pendidikan anak usia dini memberikan manfaat yang sangat besar untuk berbagai aspek perkembangan anak", sehingga peneliti menekankan betapa pentingnya pembelajaran sains yang dimulai sejak dini, karena pembelajaran sains berperan penting dalam meningkatkan mutu pendidikan, khususnya untuk menghasilkan manusia yang berkualitas yaitu manusia yang berpikir kritis, kreatif, dan logis.

Di Indonesia, pentingnya sains ditunjukkan dengan dijadikannya proses sains sebagai pendekatan pembelajaran pada Kurikulum 2013 yang menggunakan pendekatan saintifik. Pendekatan saintifik, dimaksudkan untuk memberi pemahaman 
pada anak dalam memahami, mempraktikan, dan mengetahui apa yang sedang dipelajari secara ilmiah atau proses keilmuan. (Ibrahim, 2015)

Keterampilan proses sains bagi anak menurut Charlesworth \& Lind (2010) meliputi, "Kemampuan mengamati, menanya, mengumpulkan informasi, menalar dan mengomunikasikan." Dengan demikian, pada proses pembelajaran, anak akan belajar mencari tahu berbagai sumber melalui proses mengamati, menanya, mengumpulkan informasi, menalar, dan mengomunikasikan.

Tetapi, ketika peneliti melakukan observasi pada tanggal 03 februari 2020, di RA At-Taufiq yang beralamat di Kecamatan Cibeureum Kota Tasikmalaya, peneliti menemukan bahwa masih ada anak yang kurang berkonsentrasi penuh terhadap pembelajaran sains yang diberikan guru. Adapun kurangnya pengetahuan anak dalam pembelajaran sains, karena ketika proses kegiatan pembelajaran, guru kurang memberi kesempatan pada anak untuk terlibat aktif. Selain itu pembelajaran sains yang di terapkan belum seutuhnya mengacu pada pembelajaran PAUD yang mana pembelajaran dilakukan sambil bermain karena dunia anak adalah dunia bermain.

Dengan menerapkan kegiatan pembelajaran di TK atau PAUD berorientasi sains, anak mendapat kesempatan untuk terlibat langsung dalam kegiatan, karena dengan melibatkan anak, anak akan aktif untuk menemukan jawaban dari masalah yang dipelajari ketika kegiatan pembelajaran. Ketika anak terlibat aktif dalam kegiatan pembelajaran, anak akan menggunakan seluruh panca indera untuk belajar dengan memperhatikan lingkungan sekitar dengan cara mengamati.

Menurut Funk (dalam Dimyati \& Mudjiono, 1994:128), mengamati merupakan proses pengumpulan data tentang fenomena atau peristiwa dengan menggunakan inderanya. Untuk dapat menguasai keterampilan mengamati, anak harus menggunakan sebanyak mungkin inderanya, yakni penglihatan, pendengaran, perabaan, penciuman, dan perasa. Dengan demikian dapat mengumpulkan fakta-fakta yang relevan dan memadai.

Dengan mengamati, anak mempelajari dunia dan sekitarnya. Anak mengamati peristiwa dan fenomena alam menggunakan panca indera. Informasi, fakta, dan data yang diperoleh akan mendorong keinginan serta semangat dalam belajar, memunculkan pertanyaan, menumbuhkan pemahaman terhadap lingkungan, serta memotivasi untuk melakukan kegiatan pembelajaran selanjutnya.

Maka sehubungan dengan hal tersebut, peneliti mencoba meneliti kebutuhan dasar untuk mengembangkan sebuah rencana kegiatan pembelajaran berorientasi sains pada sub tema air, dengan memfokuskan kegiatan untuk mengoptimalkan keterampilan mengamati anak usia dini.

Dengan adanya dasar kebutuhan untuk mengembangkan rencana kegiatan pembelajaran berorientasi sains pada sub tema air untuk mengoptimalkan keterampilan mengamati anak usia dini, diharapkan dapat mempermudah perancangan produk rencana kegiatan pembelajaran untuk memperbaiki keberhasilan pembelajaran, dan memotivasi serta mendorong anak untuk lebih tertarik pada kegiatan pembelajaran yang menyenangkan.

\section{TINJAUAN PUSTAKA}

\section{a. Kegiatan Pembelajaran untuk PAUD}

Kegiatan

pembelajaran merupakan suatu aktivitas yang terdiri dari serangkaian kegiatan hubungan timbal balik antara guru dan siswa yang berlangsung dalam situasi 
edukatif untuk mencapai tujuan tertentu. Menurut Winarno (1983) bahwa :

Pembelajaran adalah proses berlangsungnya kegiatan belajar dan membelajarkan siswa dikelas. Pelaksanaan pembelajaran adalah interaksi guru dan siswa dalam rangka menyampaikan bahan pelajaran kepada siswa dan untuk mencapai tujuan pembelajaran.

Kegiatan pembelajaran untuk anak usia dini adalah proses interaksi secara sadar antara anak dengan orang dewasa dalam kegiatan yang direncanakan untuk melatih anak tumbuh dan berkembang ke arah yang lebih baik agar tercapai tugas serta tujuan perkembangan.

Greeberg (dalam Isjoni, 2006) menggambarkan bahwa "Pembelajaran dapat efektif jika anak dapat belajar melalui bekerja, bermain dan hidup bersama dengan lingkungannya". Dengan demikian, anak usia dini akan belajar melalui bermain dan belajar seraya bermain agar anak tidak merasa bosan ketika pembelajaran disesuaikan dengan karakteristik anak.

Untuk itu kegiatan pembelajaran anak usia dini harus dirancang semenarik mungkin sesuai dengan karkateristik yang dimiliki anak, agar anak merasa senang dan nyaman ketika mengembangkan seluruh aspek pengembangan anak. Kegiatan pembelajaran yang akan dilaksanakan harus mengacu pada apa yang dimiliki anak. Setiap anak akan membawa pengetahuan yang dimilikinya terhadap pengalaman baru.

\section{b. Rencana Kegiatan Pembelajaran} untuk PAUD

Pembelajaran merupakan aktivitas berupa interakasi antara seseorang dalam suasana yang direncanakan secara teratur, agar berlangsung secara sistematis. Untuk melaksanakan pembelajaran yang sistematis, maka dibutuhkan suatu rancangan kegiatan pembelajaran untuk memudahkan pembelajaran yang akan dilaksanakan oleh guru dan murid agar tujuan pembelajaran dapat terlaksana dengan efektif dan efisien.

Rencana kegiatan pembelajaran merupakan penjabaran serta pengembangan dari kurikulum. Terry (dalam Majid, 2006:16) "Menyatakan bahwa perencanaan adalah menetapkan pekerjaan yang harus dilaksanakan oleh kelompok untuk dapat mencapai tujuan yang telah digariskan". Untuk itu, ketika melaksanakan suatu kegiatan ataupun pekerjaan, sangat dibutuhkan suatu rancangan atau perencaan agar kegiatan terlaksana dengan sistematis untuk mencapai suatu tujuan yang ingin dicapai.

\section{c. Ruang Lingkup Pembelajaran Sains}

Menurut KBBI, ruang lingkup berarti luasnya subjek yang tercakup. Maka ruang lingkup merupakan suatu batasan. Dalam hal ini, maka ruang lingkup pembelajaran sains pada anak disajikan pada tabel berikut :

Ruang Lingkup Pembelajaran Sains untuk Anak

\begin{tabular}{|l|l|l|}
\hline No & $\begin{array}{l}\text { Ruang } \\
\text { Lingkup } \\
\text { Sains }\end{array}$ & Deskripsi \\
\hline 1 & Proses & $\begin{array}{l}\text { Meliputi } \\
\text { kemampuan anak } \\
\text { dalam mengamati, } \\
\text { bertanya, } \\
\text { mengumpulkan } \\
\text { informasi, menalar, } \\
\text { dan } \\
\text { mengomunikasikan. }\end{array}$ \\
\hline 2 & Produk & $\begin{array}{l}\text { Meliputi kegiatan } \\
\text { mengungkap fakta, } \\
\text { data, atau suatu } \\
\text { konsep terhadap } \\
\text { fenomena atau }\end{array}$ \\
\hline
\end{tabular}




\begin{tabular}{|l|l|l|}
\hline & & peristiwa. \\
\hline 3 & Sikap & Meliputi \\
& & penanaman sikap \\
& & $\begin{array}{l}\text { ilmiah dalam diri } \\
\text { anak ketika proses } \\
\end{array}$ \\
& & kegiatan. \\
\hline
\end{tabular}

\section{d. Pembelajaran Sains untuk AUD}

Pembelajaran anak usia dini mempunyai prinsip yaitu didasarkan pada belajar sambil bermain, bermain seraya belajar, yaitu setiap anak memperolah pengetahuan ketika mereka bermain, yang dapat menumbuh kembangkan anak sehingga anak akan berkembang dengan optimal. Berbagai strategi pembelajaran dapat dilakukan tanpa mengesampingkan tahapan dan tumbuh kembang anak.

$$
\text { Sujiono }
$$

mengemukakan lima prinsip pembelajaran anak usia dini yaitu "(1) Anak sebagai pembelajar yang aktif, (2) anak belajar melalui sensori dan panca indera, (3) anak membangun pengetahuan sendiri, (4) anak berpikir melalui benda konkrit, (5) anak belajar dari lingkungan." Dengan demikian dapat disimpulkan bahwa, prinsip pembelajaran anak usia dini meliputi anak sebagai pembelajar yang aktif, anak belajar melalui sensori dan panca indera, anak membangun pengetahuan sendiri, anak berpikir melalui benda konkrit serta anak belajar dari lingkungan.

Pembelajaran sains, harus dikenalkan sejak dini. Pembelajaran sains untuk anak usia dini, dilaksanakan melalui kegiatan menyenangkan melalui pembiasaan, agar anak terlibat langsung dalam proses sains. Dengan demikian, anak tidak hanya mengetahui hasil kegiatan, tetapi anak juga akan mengerti proses kegiatan sains yang terjadi. Pembelajaran sains untuk anak usia dini, merupakan pengenalan konsep kealaman dan upaya membantu anak menemukan proses serta konsep tertentu dalam kehidupan. Sehingga, pembelajaran sains bagi anak usia dini hakikatnya dijadikan sebagai media, untuk menstimulasi seluruh aspek perkembangan dan mengoptimalkan segala potensi dalam diri anak. (Gross, 2012: 1-2).

Eshach and Fried (dalam Trundle, 2009; Mirawati \& Rini, 2017) menyatakan bahwa pembelajaran sains bagi anak usia dini, memberikan pengalaman positif yang membantu anak untuk mengembangkan pemahaman suatu konsep sains, mengembangkan kemampuan berpikir anak, menanamkan sikap positif, dan memberikan landasan kuat untuk mengembangkan konsep sains pada jenjang pendidikan selanjutnya.

Selanjutnya, Worms, Shadow and Whirlpools (dalam Halverson, 2007; Mirawati \& Rini, 2017), menyatakan terkait manfaat pembelajaran sains pada anak usia dini, yaitu mampu memupuk rasa percaya diri pada anak, memberikan pengalaman penting pada anak secara langsung, mengembangkan konsep dasar pengetahuan alam, meningkatkan kemampuan mengamati, memperoleh kesempatan untuk menggunakan material yang biasa digunakan dalam pembelajaran sains, sehingga anak mulai terbiasa sejak dini, memperoleh bantuan dalam memecahkan masalah, mendapat kesempatan untuk menstimulasikan rasa keingintahuan mereka dan mendapatkan kesempatan untuk bereksplorasi, mengembangkan kemampuan sensori, fisik, intelektual, emosional, spiritual, dan sosial, serta mengembangkan kemampuan berbahasa melalui penambahahan kosakata ketika anak melakukan 
kegiatan menanya dan menjawab pertanyaan.

\section{e. Kegiatan Sains untuk AUD}

Kegiatan sains untuk anak usia dini hendaknya disesuaikan dengan tingkat perkembangannya. Menurut Andini (dalam Hidayah, 2017), kegiatan sains penting bagi anak usia dini karena memiliki manfaat seperti:

1. Menumbuhkan semangat eksplorasi, yaitu melalui kegiatan mengamati dan menyelidiki objek serta fenomena atau peristiwa alam.

2. Mengembangkan keterampilan proses sains dasar, seperti melakukan pengamatan, mengukur, serta mengomunikasikan hasil pengamatan.

3. Mengembangkan rasa ingin tahu, perasaan senang, serta kemauan melakukan kegiatan penemuan.

4. Memperoleh pengetahuan tentang berbagai benda, baik ciri, struktur, maupun fungsinya

Selanjutnya Andini (dalam Hidayah, 2017) mengungkapkan, kegiatan atau materi pembelajaran sains sangat berkaitan dengan mencari tahu, terkait fenomena atau peristiwa alam secara sistematis. Sehingga, tidak hanya mempelajari pengetahuan tentang kumpulan fakta, prinsip dan konsep, tetapi juga merupakan proses untuk menghasilkan produk berupa penemuan. Pendidikan sains menekankan pada pemberian pengalaman langsung untuk mengembangkan kompetensi agar siswa mampu memahami alam sekitar secara alamiah. Pendidikan sains diarahkan untuk memperoleh pemahaman yang lebih mendalam tentang alam sekitar.

f. Keterampilan Mengamati pada Kegiatan Sains Sub Tema Air Mengamati merupakan kemampuan untuk menjelaskan objek atau sesuatu dengan panca indera (penglihatan, penciuman, pendengaran, peraba, dan perasa). Menurut Laily (2017, hlm. 18), keterampilan mengamati merupakan keterampilan proses yang sangat penting dan merupakan inti dalam sains adalah observasi, yang berawal dari observasi inilah maka anak akan melanjutkan penyelidikan mereka dengan membandingkan, mengklasifikasikan, mengukur, mengkomunikasikan, menyimpulkan, dan memprediksi.

Vygotsky (dalam Sujiono 2006) mengungkapkan bahwa, manusia lahir dengan seperangkat fungsi dasar yakni kemampuan memperhatikan, mengamati dan mengingat. Berikut keterampilan mengamati menggunakan seluruh panca indera :

1. Melihat, yaitu mengamati menggunakan indera penglihatan yaitu mata. Melihat bertujuan untuk mengetahui berupa wujud, bentuk, maupun warna pada objek atau suatu peristiwa yang sedang diamati.

2. Mendengar, yaitu mengamati menggunakan indera pendengaran berupa telinga, agar mengetahui bunyi atau suara dari objek yang diamati.

3. Mencicipi atau merasa, merupakan pengamatan dengan menggunakan indera pengecap yaitu lidah. Bertujuan untuk mengetahui suatu rasa dari objek yang diamati.

4. Meraba, merupakan pengamatan menggunakan indera peraba yaitu kulit. Dilakukan untuk mengetahui tekstur kasar atau halus, panas atau dingin dari suatu objek yang sedang diamati.

5. Menghidu, merupakan pengamatan menggunakan indera penghidu yaitu hidung, untuk mengetahui bau dari suatu objek.

Untuk

mengoptimalkan keterampilan mengamati pada anak 
usia dini, maka kegiatan untuk sub tema air yang telah dipilih untuk dilaksanakan dalam rencana kegiatan pembelajaran, mencoba dilakukan dengan memaksimalkan proses mengamati pada anak, semua kegiatan mengoptimalkan penggunaan seluruh indera anak.

Anak adalah pembelajar alamiah, karena melalui panca inderanya anak mampu mengamati peristiwa maupun fenomena alam sekitar. Maka dengan mengamati lingkungan sekitar, anak memperoleh pengalaman belajar menyenangkan yang akan terus diingat oleh anak.

Dengan demikian, perlu upaya untuk memfasilitasi pertumbuhan serta perkembangan dengan menyesuaikan kegiatan pembelajaran dengan miant, kebutuhan, dan usia anak. Mengenalkan sains harus diterapkan sejak usia dini melalui kegiatan menyenangkan dalam proses pembelajaran, agar anak terlibat langsung mengalami proses sains. Dengan begitu, anak tidak hanya mengetahui produk atau hasil akhir, tetapi mengerti juga bagaimana kegiatan pembelajaran pada proses sains yang berlangsung.

\section{g. Kegiatan Pembelajaran Sains Sub} Tema Air

Kegiatan pembelajaran atau pengenalan sains untuk anak usia dini, harus sesuai dengan karakter dan aspek perkembangan anak. Guru merupakan motivator untuk mendorong anak, belajar menemukan fakta serta konsep sederhana. Menurut depdiknas (dalam Nurhafizah, 2017) Kegiatan sains akan mengeksplorasi anak terhadap suatu objek atau benda, baik benda hidup maupun tak hidup di sekitarnya. Mengingat luasnya materi pembelajaran sains topik air untuk anak usia dini, sehingga perlu adanya fokus tentang materi sains, yaitu tidak semua permainan dengan air dipilih dan dilakukan.

Oleh karena itu, kegiatan pembelajaran difokuskan pada beberapa jenis kegiatan bermain air, yaitu :

1. Anak dikenalkan tentang sifat-sifat air bahwa air dapat melarutkan berbagai zat pada kegiatan percobaan "Gabungan Air Warna"

2. Anak akan mengenal warna dan penggabungan warna

Dari beberapa jenis kegiatan diatas, diharapkan anak melihat dan mengetahui langsung proses dan produk dari kegiatan percobaan yang dilakukan dengan metode bermain, selain itu media yang digunakan tidak membahayakan bagi anak.

\section{METODE}

Metode penelitian merupakan rangkaian berupa kegiatan pelaksanaan penelitian dengan didasari asumsi-asumsi dasar, pandangan filosofis, ideologis, dan isu-isu yang dihadapi (Sukmadinata, 2013, hlm. 52). Menurut Arikunto (2006;1630) "Metode penelitian adalah cara yang digunakan peneliti dalam mengumpulkan data penelitiannya".

Metode penelitian yang digunakan yaitu penelitian pengembangan menggunakan pendekatan mix method dengan tekhnik Educational Design Research (EDR). Menurut Barab dan Squire (dalam Akker, dkk., 2006, hlm. 5), EDR merupakan "Serangkaian pendekatan, dengan maksud menghasilkan teori baru, artefak, dan praktik yang menjelaskan dan berpotensi berdampak pada pembelajaran dan pengajaran dalam pengaturan naturalistik". Dengan demikian, peneliti menggunakan tekhnik penelitian Educational Design Research (EDR) bertujuan untuk mengembangkan hasil penelitian terkait produk pendidikan, yaitu berupa rencana kegiatan pembelajaran berorientasi sains di PAUD. 
Menurut Borg dan Gall (dalam Moh. Ainin, 2013), "Penelitian pengembangan adalah suatu desain penelitian yang bertujuan untuk mengembangkan dan memvalidasi produk pendidikan". Selanjutnya, Lidinillah (2012, hlm. 1) mengungkapkan "Design research dapat diterapkan untuk penelitian pengembangan program pendidikan dan pelatihan, pengembangan kurikulum serta pengembangan model pembelajaran di kelas". Selain itu, menurut Plomp (dalam Lidinillah, 2012, hlm. 4) design research sebagai

Suatu kajian sistematis tentang merancang, mengembangkan dan mengevaluasi intervensi pendidikan (seperti program, stategi dan bahan pembelajaran, produk dan sistem) sebagai solusi untuk memecahkan masalah yang kompleks dalam praktik pendidikan, yang juga bertujuan untuk memajukan pengetahuan kita tentang karakteristik dari intervensi-intervensi tersebut serta proses perancangan dan pengembangannya.

Berdasarkan uraian tersebut, model penelitian Educational Design Research (EDR) sebagai tekhnik penelitian dianggap relevan, untuk fokus penelitian yaitu mengembangkan kebutuhan dasar rencana kegiatan pembelajaran berorientasi sains pada subtema air untuk mengoptimalkan keterampilan mengamati anak usia dini, karena dianggap mampu menjadi jembatan untuk mengembangkan teori dan menghasilkan pembelajaran yang efektif serta praktis.

\section{a. Desain Penelitian}

Menurut Creswell (2017, hlm. 3), "Rancangan penelitian merupakan rencana dan prosedur penelitian yang meliputi asumsi-asumsi luas hingga metode rinci dalam pengumpulan dan analisis data." Maka, desain atau rancangan pada penelitian merupakan pedoman atau langkah untuk merencanakan penelitian, sebagai acuan untuk menciptakan strategi dan langkah untuk menghasilkan penelitian.

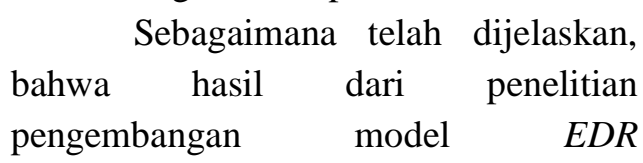
(Educational Design Research) adalah berupa produk pendidikan. Produk yang dikembangkan bukan produk sembarangan, melainkan produk yang telah didesain untuk disesuaikan dengan permasalahan yang dihadapi dalam pembelajaran (Moh. Ainin, 2013). Dengan demikian, hasil observasi di lapangan terkait permasalahan, peneliti menemukan masalah terkait kurangnya pengoptimalan keterampilan proses sains dalam kegiatan pembelajaran di PAUD.

Maka, peneliti mencoba merancang produk pendidikan untuk pembelajaran berupa dasar kebutuhan pengembangan rencana kegiatan pembelajaran berorientasi sains subtema air untuk mengoptimalkan keterampilan mengamati anak usia dini ini.

Metode penelitian dan pengembangan yang digunakan, mengacu pada model pengembangan EDR menurut McKenney \& Reeves (2012), sebagai berikut :

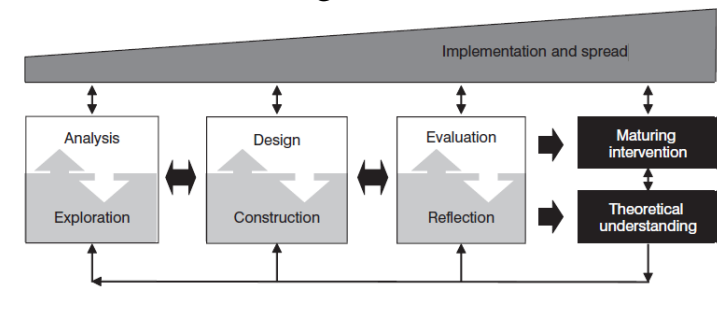

Mengacu pada model generik EDR menurut McKenney \& Reeves, maka proses tahapan penelitian yang akan dilakukan hanya eksplorasi dan analisis masalah karena peneliti hanya menjelaskan terkait dasar kebutuhan untuk pengembangan rencana kegiatan pembelajaran, tahap tersebut yaitu: 
1) Tahap Eksplorasi dan Analisis

Pada tahap ini, peneliti melakukan tahap eksplorasi dan analisis masalah terkait dasar kebutuhan untuk pengembangan rencana kegiatan pembelajaran berorientasi sains sub tema air untuk mengoptimalkan keterampilan mengamati anak usia dini.

Tahap eksplorasi dan analisis masalah merupakan tahap pengumpulan data yang diteliti, dengan menganalisis serta mengeksplorasi masalah. Maka, tahap eksplorasi dan analisis dilakukan dengan mengumpulkan data melalui studi pendahuluan.

Pada tahap eksplorasi dan analisis, peneliti melakukan studi pendahuluan untuk mengeksplorasi serta menganalisis masalah melalui observasi di lapangan dan mengkaji literatur. Studi pendahuluan adalah langkah pertama yang dilaksanakan dalam penelitian pengembangan model EDR, bertujuan agar menghasilkan produk yang relevan dengan kebutuhan di lapangan. Berikut penjelasan terkait pelaksanaan studi pendahuluan :

a) Studi Lapangan

Tahap pertama dalam melakukan studi pendahuluan yaitu, peneliti melaksanakan studi lapangan dengan observasi ke sejumlah TK atau PAUD yang ada di Tasikmalaya terutama berfokus pada RA At-Taufiq yang beralamat di Kecamatan Cibeureum, Kota Tasikmalaya.

b) Studi Literatur

Tahap selanjutnya, peneliti melakukan kajian literatur pada buku-buku terkait materi pembelajaran sains untuk anak usia dini, manfaat serta pentingnya sains untuk diterapkan sejak usia dini.
Mempelajari pendekatan saintifik yang merupakan keterampilan proses sains anak, terutama pada keterampilan mengamati. Selain pada buku, peneliti pun mengkaji artikel dan jurnal ilmiah mengenai kegiatan pembelajaran yang menyenangkan dan cocok di PAUD, untuk dikembangkan dan disusun menjadi rancangan kegiatan pembelajaran berorientasi sains untuk mengoptimalkan keterampilan proses sains anak usia dini.

\section{HASIL DAN PEMBAHASAN}

Berikut hasil dan pembahasan terkait "Dasar Kebutuhan Pengembangan Rencana Kegiatan Pembelajaran Berorientasi Sains pada Sub Tema Air untuk Mengoptimalkan Keterampilan Mengamati AUD."

Penelitian pengembangan ini, bertujuan untuk mengetahui dasar kebutuhan untuk pengembangan rencana kegiatan pembelajaran berorientasi sains pada subtema air untuk mengoptimalkan keterampilan mengamati anak usia dini.

\section{a. Pembahasan}

Pengembangan dasar kebutuhan rencana kegiatan pembelajaran berorientasi sains pada subtema air untuk mengoptimalkan keterampilan mengamati anak usia dini, mengacu pada model generik EDR menurut McKenney \& Reeves. Tetapi, peneliti hanya menjelaskan dasar kebutuhan pengembangan rencana kegiatan pembelajaran yaitu tahap eksplorasi dan analisis masalah, dilakukan dengan studi pendahuluan yaitu dengan studi lapangan dan studi literatur, dijelaskan sebagai berikut :

1) Pembahasan hasil studi lapangan

Berdasarkan observasi lapangan di beberapa sekolah PAUD yang ada di Tasikmalaya, terutama di RA AtTaufiq pada kelompok A, yang beralamat di Kecamatan Cibeureum, peneliti mendapat informasi bahwa pembelajaran yang berorientasi pada 
sains belum optimal dan masih kurang diterapkan. Guru hanya menjelaskan dengan metode ceramah kemudian dilakukan latihan pada lembar kerja anak, hal tersebut mempengaruhi pada kurangnya mengoptimalkan keterampilan proses sains pada anak usia dini. Sedangkan, seharusnya dalam kegiatan sains anak terlibat langsung untuk aktif, melakukan percobaan atau eksperimen, dengan demikian kegiatan pembelajaran tidak mudah bosan, dan akan menyenangkan bagi anak. Maka, pengoptimalan pembelajaran sains akan berjalan secara efektif dan efisien serta tersampaikan dengan semestinya.

2) Pembahasan hasil studi literatur

Untuk dasar kebutuhan pengembangan rencana kegiatan pembelajaran, peneliti mengumpulkan informasi untuk dijadikan bahan pembuatan produk dan mengkaji literatur dari buku penyusunan rencana pelaksanaan pembelajaran yang dikeluarkan oleh Direktorat Jendral PAUD dan Pendidikan Masyarakat serta jurnal yang berkaitan dengan materi sains untuk anak usia dini dan rencana kegiatan pembelajaran sains AUD.

Berdasarkan analisis masalah melalui observasi lapangan dan melakukan kajian literatur, peneliti mendapat solusi untuk mengatasi permasalahan yang ditemukan dilapangan selama observasi, yakni mengembangkan rencana kegiatan pembelajaran berorientasi sains pada subtema air untuk mengoptimalkan keterampilan mengamati anak usia dini.

Dengan adanya dasar kebutuhan pengembangan rencana kegiatan pembelajaran berorientasi sains, diharapkan anak mampu mengoptimalkan keterampilan proses sains karena dalam kurikulum 2013
PAUD menggunakan pendekatan saintifik dengan keterampilan proses sains.

b. Hasil

Setelah mendapat informasi mengenai permasalahan yang akan diteliti, peneliti melakukan kajian terkait data informasi dari hasil eksplorasi dan analisis masalah. Maka hasil eksplorasi dan analisis masalah, didapatkan informasi berdasarkan :

1) Landasan Teori

Setelah melakukan eksplorasi dan analisis masalah melalui studi literatur menggunakan buku serta jurnal ilmiah penelitian, peneliti menemukan landasan teori terkait produk yang akan dikembangkan yaitu berupa rancangan kegiatan pembelajaran yang berorientasi sains untuk anak usia dini.

Landasan teori terkait penyusunan kegiatan pembelajaran serta kegiatan pembelajaran sains yang cocok, menarik, dan sesuai dengan karakteristik anak. Landasan teori digunakan sebagai langkah awal peneliti, untuk menyusun produk berupa rancangan kegiatan agar tercipta kegiatan pembelajaran yang aktif, ilmiah dan inovatif untuk keberlangsungan hidup manusia selanjutnya.

2) Kurikulum

Kurikulum merupakan acuan atau pedoman peneliti, sebelum menyusun rancangan kegiatan pembelajaran berorientasi sains. Kurikulum digunakan untuk mengetahui kebutuhan atau komponen untuk rancangan kegiatan pembelajaran anak usia dini, seperti tema atau sub tema yang dipilih, materi pembelajaran, tujuan pembelajaran, kompetensi dasar serta indikator yang hendak dicapai ketika pembelajaran berlangsung. 
Membuat atau menyusun produk pendidikan berupa rancangan kegiatan pembelajaran untuk anak usia dini, peneliti terlebih dulu menganalisis kurikulum dengan pendekatan saintifik yaitu kurikulum 2013. Rancangan kegiatan pembelajaran disusun dengan berorientasi pada sains, karena dalam kurikulum 2013 menuntut anak untuk mengembangkan keterampilan sains untuk menjadikan manusia selanjutnya yang berpikir kritis dan cerdas.

Maka, pemilihan tema yang digunakan dalam rencana kegiatan pembelajaran berorientasi sains, disesuaikan dengan tema yang mengoptimalkan kegiatan sains untuk memaksimalkan keterampilan proses sains yaitu mengamati pada anak usia dini. Tema yang dipilih yaitu tema alam semesta, dengan sub tema benda-benda alam, dan sub-sub temanya yaitu air. Topik air sangat difokuskan pada rencana kegiatan pembelajaran berorientasi sains yang disusun peneliti ini.

3) Tuntutan Kebutuhan Lapangan

Berdasarkan hasil eksplorasi dan analisis masalah melalui observasi lapangan, peneliti mendapatkan informasi terkait kebutuhan lapangan yaitu terkait kurangnya pengoptimalan keterampilan proses sains dalam kegiatan pembelajaran di PAUD, kegiatan pembelajaran yang dilaksanakan masih kurang melibatkan anak aktif melaksanakan kegiatan sains. Sedangkan, anak usia dini akan belajar langsung melalui pengamatan, maka kegiatan harus dirancang semenarik mungkin untuk mendorong anak melakukan permainan langsung karena prinsip anak adalah belajar sambil bermain, agar anak aktif melakukan kegiatan pembelajaran sains.
Dengan demikian, peneliti mencoba menjelaskan dasar kebutuhan untuk pengembangan rencana kegiatan pembelajaran berorientasi sains untuk mengoptimalkan keterampilan mengamati anak usia dini, dalam bentuk produk rencana kegiatan pembelajaran yang nantinya untuk kebutuhan dalam pembuatan rencana pelaksanaan pembelajaran harian (RPPH).

\section{KESIMPULAN}

Berdasarkan hasil penelitian, dapat disimpulkan bahwa dasar kebutuhan "Dasar Kebutuhan Pengembangan Rencana Kegiatan Pembelajaran Berorientasi Sains pada Sub Tema Air untuk Mengoptimalkan Keterampilan Mengamati AUD", berdasarkan hasil studi lapangan dan studi literatur untuk mendapatkan informasi terkait kebutuhan dasar untuk pengembangan rencana kegiatan pembelajaran, yaitu :

a. Landasan teori

b. Kurikulum

c. Tuntutan kebutuhan lapangan

Setelah mendapat informasi dan data terkait dasar kebutuhan, maka data tersebut sangat dibutuhkan untuk tahap penelitian selanjutnya yaitu membuat serta menyusun produk berupa rencana kegiatan pembelajaran untuk kebutuhan penyusunana rencana pelaksanaan pembelajaran harian di PAUD.

6. SARAN

Berdasarkan hasil penelitian maka dapat disarankan, dasar kebutuhan rencana kegiatan pembelajaran berorientasi sains pada sub tema air yang telah dikembangkan, diharapkan dapat digunakan untuk penyusunan rencana kegiatan pembelajaran berorientasi sains di PAUD, sehingga dapat mengoptimalkan keterampilan proses sains mengamati anak usia dini.

\section{DAFTAR PUSTAKA}

Adadan, E., Irving, KE., \& Trundle, KC., (2009). Impacts of 
MultiRepresentational Instructionon High School Students' Conceptual Understandings of the Particulate Nature of Matter. International Journal of Science Education, vol. 31 (13), hlm. 1743-1775.

Ainin, M. (2013). Penelitian Pengembangan dalam Pembelajaran Bahasa Arab. Jurnal pendidikan ilmiah, vol. 2 (8), hlm. 96-110.

Akker J., dkk. (2006). Educational Design Research. London and New York: Routledge.

Arikunto, Suharsimi. (2006). Prosedur Penelitian Suatu Pendekatan Praktik. Jakarta: Rineka Cipta.

Atmojo, S.E. (2013) Penerapaan Model Pembelajaran Berbasis Masalah Dalam Peningkatan Hasil Belajar Pengelolaan Lingkungan. Jurnal Kependidikan: Penelitian Inovasi Pembelajaran, vol. 43 (2).

Charlesworth, R \& Lind, K. (2010) Math and Science. Amerika Serikat : Six Edition.

Creswell, J. W. (2017) Research Design: Pendekatan Metode Kualitatif, Kuantitatif, Dan Campuran Edisi 4 Terjemahan. Yogyakarta: Pustaka pelajar.

Dimyati \& Mudjiono. (1994). Belajar dan Mengajar. Jakarta: Rineka Cipta.

Halverson, A. M. D. (2007). Hemorrhoids, Clinics in Colon and Rectal Surgery. vol. 20 (2), hlm 77-85.

Gross, C. M. (2012). Science Concepts Young Children Learn Through Water Play. Dimensions of Early Childhood, vol. 40 (2).

Hidayah, N. (2017). Implementasi Pembelajaran Keterampilan Sains di Tk Al-Faruq Tanjung Morawa. Skripsi

Ibrahim. (2015). Metodologi Penelitian Kualitatif Panduan Penelitian beserta Contoh Proposal Kualitatif. Pontianak: Perpustkaan Nasional.

Isjoni. (2006). Membangun Visi Bersama : Aspek-Aspek Penting dalam Reformasi
Pendidikan. Jakarta : Yayasan Obor Indonesia.

Laily, NA. (2017). Peningkatan Keterampilan Proses Sains Dasar Dengan Pendekatan Open-Inquiry. vol. 6 (1), hlm. 13-30.

Lidinillah, D. A. M. (2012). Educational Design Research : a Theoretical Framework for Action. Tasikmalaya: Universitas Pendidikan Indonesia Kampus Tasikmalaya

Laily, N. A. (2017). Peningkatan Keterampilan Proses Sains Dasar Dengan Pendekatan Open-Inquiry. vol. 6 (1), hlm. 13-30.

Majid, A. (2006). Perencanaan Pembelajaran. Bandung: PT Remaja. Rosdakarya.

McKenney, S., \& Reeves, TC. (2012). Conducting Educational Design Research. London: Routledge.

Mirawati \& Rini. (2017). Meningkatkan Keterampilan Proses Sains Anak Usia Dini Melalui Aktivitas Berkebun. Early Childhood: Jurnal Pendidikan, vol. 1 (1).

Nurhafizah. (2017). Strategi Pengembangan Kemampuan Sains Anak Taman KanakKanak di Koto Tangah Padang. Pedagogi: Jurnal Anak Usia Dini dan Pendidikan Anak Usia Dini, vol. 3 (3b).

Sujiono, YN. (2006). Metode Pengembangan Kognitif. Jakarta: Universitas Terbuka.

Sujiono, YN. (2013). Konsep Dasar Pendidikan Anak Usia Dini. Jakarta Barat: Indeks.

Sukmadinata, NS. (2013). Metode Penelitian Pendidikan. Bandung : PT Remaja Rosdakarya.

Sund \& Corring. (1993). Metode Pembelajaran Terpadu dalam Teori dan Praktek. Jakarta: PT Remaja Rosdakarya.

Trundle, K.C., Bell, R.L. (2010). The Use of A Computer Simulation to Promote Conceptual Change: A QuasiExperimental Study. Computers \& Education, Elsevier, hlm. 1078-1088.

Winarno (1983). Enzim Pangan. Jakarta : Gramedia. 